DOI:

\title{
Pilgrimage Sites - Heritage Sites: The Evaluation of Authenticity of Selected Cases
}

\author{
Alaa E. El-Habashi ${ }^{1}$, and Samah H. El-Refai ${ }^{2}$ \\ ${ }^{I}$ Department of Architecture Eng., Faculty of Eng., Menoufia University, Egypt. \\ ${ }^{2}$ MSc Candidate, Department of Architecture Eng., Faculty of Eng., Menoufia University, Egypt. \\ (Corresponding author: samah.hisham88@gmail.com)
}

\begin{abstract}
Preserving heritage sites promotes local identities and strengthens their link with local communities. It also raises pride that encourages locals to invite others to visit and celebrate. It is thus crucial to involve all parties in managing heritage sites to ensure sustainability. Such principles are challenging if the subject is a pilgrimage site due to its moral association with different cultures embracing the religion. The presentation/interpretation of the historical attributes in pilgrimage sites is crucial to reflect their religious association as well as to respect historical facts. Accentuating authenticity also strengthens the bond of the believers. The mandate is then protecting those valuable attributes, which are usually marginalized due to the tyranny of some spiritualties and to the admission of large numbers of pilgrims to raise economic profits.

The research evaluates those contradictions in selected pilgrimage sites: Makkah in Saudi Arabia, Santiago de Compostela in Spain, and Fushimi Inari Shrine in Japan. It applies the Nara Grid to verify the authenticity of their historic attributes and to confirm that the conditions of pilgrimage in the three sites drastically differ from what they originally were. This paper points to the reasons that led to these differences, the impact on the authenticity of values and attributes, and the status of the cultural heritage if managed away from the participatory process. The research aims to draw on the results of scientific analysis of the current situation of those sites to decipher the management deficiencies affecting the authenticity of their historic attributes.
\end{abstract}

Keywords: Cultural heritage; Pilgrimage Sites; Authenticity; Nara Grid; Sustainability of Religious Sites.

\section{Introduction}

The sites of pilgrimage are among the most important elements of religious tourism where millions of visitors from all over the World come to it all at once. According to the estimates of the United Nations World Tourism Organization (UNWTO), between 300 and 330 million tourists visit the world's main religious sites every year [1]. These sites need to be managed with greater cultural awareness to achieve a balance between religious spirituality and historical facts because the visited sites and objects need to be of the proximity to the social and accommodation services. They both become inseparable from the experience itself.

Pilgrimage sites should be treated as a public good that reflects the common beliefs of the religions, besides the history of the nations where they are located. Therefore, it makes no sense to highlight certain values and attributes and ignore and obliterate others according to the trends and visions imposed by certain stakeholders of proximity to these sites. Given the sensitivities of different interpretations entailed in each religion, biased representations of some values create a state of community division and malfunctions in the management of these sites. Pilgrimage sites, therefore, cannot be solely treated as heritage sites from one side, or religiously sacred monuments from the other.

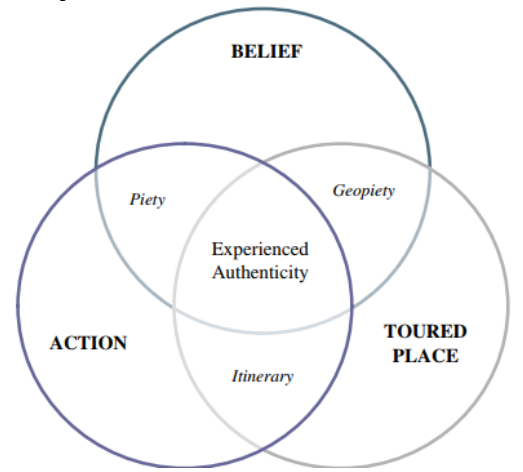

Figure 1- Authenticity Conceptual Framework [2]

This research hypothesizes that a balance between the two representations can only be achieved if the authenticity of the historic attributes existing in those sites are preserved and maintained. Authenticity bound up with the network of tangible and intangible relationships that reflect the identity of the site and its 


\section{Alaa E. El-Habashi, and Samah H. El-Refai "Pilgrimage Sites-Heritage Sites: The Evaluation of Authenticity of Selected Cases"}

preservation does not necessarily impede the sustainability of heritage sites. The authenticity of the experience of the holy sites is shaped by three interrelated components: the beliefs underlying the pilgrimage, the places visited, and the associated activities undertaken by the pilgrims (Figure 1) [2].

As such the Nara grid - a tool for assessing authenticity- is used to check on the authenticity and the integrity of preserved attributes for three internationally recognized pilgrimage sites: Makkah in Saudi Arabia, Santiago de Compostela in Spain, and Fushimi Inari Shrine in Japan.

\section{Aim and Research Significance}

The importance of selected sites lies in the fact that they are among the most important known sites of pilgrimage, and therefore subjected to mass religious tourism that put them under the constant pressure of developments and expansions. The contradictory situation in preserving the heritage attributes and allowing larger touristic groups to benefit, is usually a worrying matter for planners, conservators, and developers. This dichotomy reaches its extremes when liberal regimes take over the management system, usually jeopardizing large heritage components for the sake of admitting larger numbers of pilgrims. This research raises the question of whether a sustainable managerial system can be offered to balance between the required conservation and the allowed development if the mandate is to keep considering those sites as heritage.

\section{Nara Grid and Authenticity of cultural heritage}

Nara Document on Authenticity (1994) is based on clarifying the collective memory of humanity and respecting all cultural contexts which belong to this historical memory. In recent years, the concept of authenticity in the conservation process has been developed to include the "spirit of the place" taking the practice beyond the tangible attributes.

Nowadays authenticity is known as a concept by which the total tangible and intangible values of heritage are manifested; so that heritage values must be truthfully and credibly expressed through a variety of interrelated attributes to maintain authenticity [3]. As such, cultural heritage can relate all stories and give all images which representing true identity and fostering the emotional attachments that support feelings of loyalty and belonging.

According to the 13th article of Nara document states that authenticity judgments may be "linked to... form and design, materials and substance, use and function, traditions and techniques, location and setting, and spirit and feeling, and other internal and external factors." The use of these aspects permits the elaboration of the specific artistic, historic, social, and scientific dimensions of the cultural heritage being examined. This layered concept of authenticity was taken as the basis to develop a tool that would help to understand and measure it. The Raymond Lemaire International Center for Conservation used this trend of the Nara Document and defined it in a grid in which aspects and dimensions represent 'an axis'.

Table 1- The Nara Grid based on the Nara Document on Authenticity [4]

\begin{tabular}{|c|c|c|c|c|c|}
\hline $\begin{array}{l}\text { Aspects } \\
\qquad \downarrow\end{array}$ & $\begin{array}{c}\text { Dimensions } \\
\longrightarrow\end{array}$ & 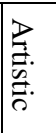 & 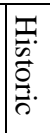 & 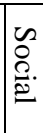 & 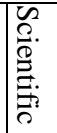 \\
\hline \multicolumn{6}{|l|}{ Form and design } \\
\hline \multicolumn{6}{|c|}{ Materials and substance } \\
\hline \multicolumn{6}{|l|}{ Use and function } \\
\hline \multicolumn{6}{|c|}{ Tradition- techniques- workmanship } \\
\hline \multicolumn{6}{|l|}{ Location and setting } \\
\hline Spirit and feeling & & & & & \\
\hline
\end{tabular}

\section{Heritage Values and Attributes}

Determining, understanding, and analyzing heritage values is crucial to assess the significance and reaching the appropriate decision in the conservation process. An important moment in the evolution of heritage conservation emerged in 1979 when Australia ICOMOS issued the Burra Charter which recognized a new class of cultural values: social values [5]. Since then, heritage value could be understood through discussion with stakeholders, reviewing documents and research related to sites that reveal its origin, identity, and other relevant characteristics. This complex process of assessment results in determining values prioritized for the communities and restore attributed elements to these values within the built environment and social fabric. Practitioners have continued to reach out to different disciplines in their attempts to identify and classify the values that reflect the emotions, meanings, and functions attributed to that heritage, beside the usual recognition of a multifaceted variety of tangible attributes, such as decorative elements, building materials, architectural elements, and others. With Nara document of 1994 aspects of those attributes were better explained, and classified, and the NARA GRID became an essential tool used for assessment of the authenticity of values. According to the Grid values are classified as:

- Artistic Value: It expresses the aesthetic aspects and their sensory perception. Its attributes appear in decorative elements, ornaments and attention to the shape, color, texture, smells. It is also expressed in the senses of the place and its surroundings. It is also found in the harmony of the site with its environment [6]. 


\section{Alaa E. El-Habashi, and Samah H. El-Refai" Pilgrimage Sites - Heritage Sites: The Evaluation of Authenticity of Selected Cases"}

- Historic Value: It includes the various stages the site has gone through since its inception, and how it relates to a specific, or a series of personalities, stages, events, or activities. It also involves the attributes of customs, traditions memorial, and associate legends [7].

- Social Value: It embraces the qualities for which a place has become a focus of spiritual, political, national, or other cultural sentiments to a majority or minority group. It plays an important role in the definition of cultural identities, social structures, the rituals, skills and livelihood activities of the residents, and defines the inhabitants' relationships with the history of the place [8].

- Scientific Value: It depends on studying the techniques used and the craftsmanship found in its creation and its relationship with the various materials, construction and manufacturing methods. It reflects the degree to which the place may contribute further substantial scientific information [9].

Accordingly, NARA GRID is based on those four "dimensions" (the horizontal row of the grid) and "aspects" (the vertical column of the grid) that would bridge between tangible and intangible attributes.

\section{Case study (1): Makkah in Saudi Arabia}

The holy city of Mecca is in the Southwest of Saudi Arabia and it is considered the spiritual capital of one and half billion Muslims worldwide. It is believed that Allah selected it to be the location of His most sacred house, the Ka'ba, the first House set up for HIS worship on earth in which He created safety for trees, plants and birds, and of which should not be ruined by HIS mercy.

Makkah is considered an economic, cultural, social and urban unit. In ancient times until the mid-twenties, the surrounding houses formed the walls of the Grand Mosque, and were considered as part of the haram, Over the past many years, the city has undergone an urban boom especially around the Holy Mosque and the sacred sites of pilgrimage. (Figure 2) It is noticeable that not only has most of the built heritage damaged, but the surrounding natural landscape has been significantly changed. Entire mountains were paved down to build towers and skyscrapers instead.

The decisions to expand the Grand Mosque in Mecca destroyed many Sunni, Shiite and secular sites, which angered many Muslims, who consider visiting tombs, shrines, and holy sites is an important part of their culture and faith. All these changes created a gap that is dangerously widening between this holy place and its visitors where the destruction of religious, historic, and cultural sites prevents people from exercising their right to visit places of worship and to enjoy and access cultural heritage sites.

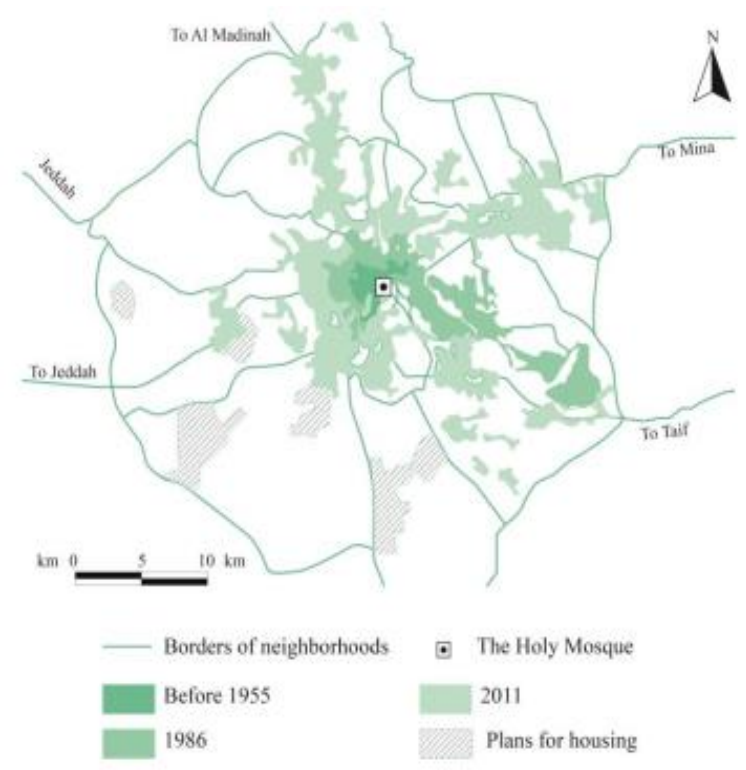

Figure 2- Geographical expansion of the Holy City of Makkah (1955 - 2011) [10]

\section{1) Urban Fabric around the Ka'ba:}

Mecca exemplifies a hyper-inflated urban condition where the rapid urban expansion in the past years destroyed most of the historical fabric surrounding the Great Mosque. The recent massive building campaigns have reshaped the landscape and the immediate traditions of the Holy Site. This urban development moved at a much faster rate than the parallel social and cultural development processes and therefore resulted in the extinction of most urban architectural heritage, not to mention the intangible cultural activities that were utterly marginalized. Most of these aspects were of little concern while the developments were taking place under the visions to admit more pilgrims. Reviewing the cultural zones in Mecca and more specifically around the Holy Ka'ba, the following can be concluded:

- Al-Haram: It was necessary to remove most of the architectural heritage that was present around the Ka'ba and the Holy Mosque to make place for the enormous expansions to accommodate the largest number of pilgrims who come from around the world. Mosques and key sites dating from the time of Prophet Muhammad (saww) have been knocked down or destroyed, as have Ottoman-era mansions and ancient wells. 


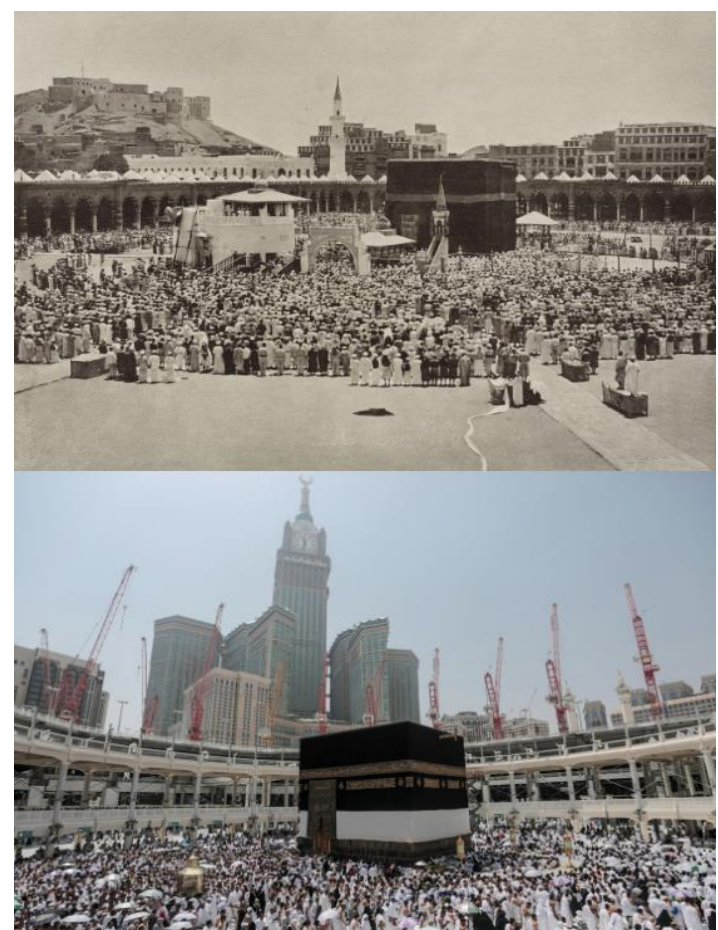

Figure 3- The Great Mosque of Mecca 1887, 2015 [12]

- The house of Khadija (the Prophet's first wife), is an extremely important attribute of Islamic history. The house of Khadijah, being the first woman to believe in the message of Islam, was demolished and in its place, a public toilet stands today [11].

- The house of Abu Bakr, who is the first companion of the Prophet and the first Islamic Caliph, was demolished to give place for Mecca Hilton Hotel to rise [11].

- The house of the grandson of the Prophet AliOraid, and the Mosque of Abu-Qubais have been replaced with the King's palace [11].

- An ancient mosque that belonged to the first Caliph Abu Bakr has been leveled down and is currently the location of an ATM [11].

- The sites of the first two main battles in Islamic history, Bader and Uhud, both led by Prophet Mohammad himself have been asphalted and paved for a parking lot [11].

- Al- Ajyad Fortress, in 2002, the 220-year-old Al-Ajyad Fortress that was built by the ruling Ottomans was demolished by the Saudi authorities to make room for the multibillion expansions. The fortress, located on a hill, overlooking the Kaaba_and the Grand Mosque, was built in the 18th century to protect Muslims from invaders. The fortress and the hill are replaced with Abraj al Bait, a series of hotel tower [11].

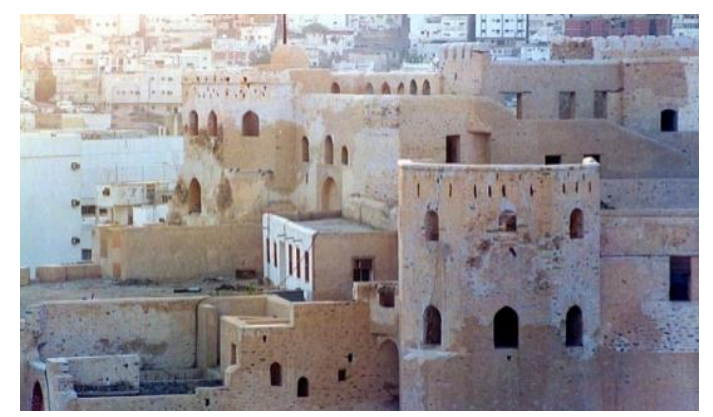

Figure 4- Ajyad Fortress Perspective [13]

Preservation problem: The holy city of Makkah comes as one of the most sensitive cases to deal with heritage because of its economic, cultural, political, social, and urban position. Therefore, any development process in the city should consider the holiness and uniqueness of this site so that it does not affect the spirituality of the Hajj and does not reduce the values of the place. The uniqueness in dealing with the heritage of this city and moving away from community participation created a state of spiritual separation from the place where attention was paid to achieving the largest possible economic return and neglecting the values of the place. The current state represents a dichotomy between the rich and respected historic events, that an unrelated contemporary form that imposes pilgrim activities in a disturbed spatial context that feels like without history or tradition. In this regard, there is a mere need to strip the process of preserving heritage sites from political trends and tendencies that is coated with religious and economic benefits.

It is worth noting that the process of preserving the heritage greatly supports the meanings and the religious message of the pilgrimage itself, as it brings back believers to the simplicity and the authenticity of the origins. Islamic principles of equality and total impartiality of material words are lost in between the numbers of stars of the hotels, and how speedy and privileged one can perform the rituals.

Values and Attributes by Nara Grid: The information collection and the urban fabric study in the Ka'ba and the developments that occurred in and around it allowed for the application of Nara Grid (Table 2). Inevitably, Mecca is the most important heritage site in Islam that is supposedly rich in various 


\section{Alaa E. El-Habashi, and Samah H. El-Refai" Pilgrimage Sites - Heritage Sites: The Evaluation of Authenticity of Selected Cases"}

historic and heritage values. It was worth preserving such invaluable heritage and unique attributes for the associated rituals to gain credibility and meanings. The brutal demolitions and distortions of these treasures with no proper interpretation, however, made it difficult to call Mecca a heritage site, and despite all such grandiose developments, it narrowed it down to be only a place for practicing the rituals of pilgrimage, usually disassociated from their meaningful contexts. Unfortunately, all these values lose their characteristics, so the pilgrims are kept in a state of mental distraction and spiritual apathy with the place. The pilgrims perform only the different rituals without feeling the spirituality that was flooding the place where the Prophet Muhammad's journey spread the religion in the World.

The matter is not only about the violations against the urban fabric, and the architectural values, but rather, it is a disfiguration of the culture and principles of the pilgrimage, which is the very essence of the site's existence. It was not surprising to find terms such as luxury pilgrimage, distinctive pilgrimage, and comfortable pilgrimage emerging in this context. The Nara Grid for Mecca is in Table 2.

\section{Case study (2): Santiago de Compostela cathedral} in Spain

The Cathedral of Santiago de Compostela is an integral component of the UNESCO World Heritage Site in Galicia, Spain. Monuments and memorials, as well as the tombs of martyrs and saints, are always a great attraction for Christian pilgrims. this was achieved in Santiago de Compostela cathedral where the tomb of St. James, which received a very high rank among the saints being one of the first apostles called by Prophet Jesus. This tomb and the relics of St. James were rediscovered in the 9th century at this magnificent cathedral. In addition to this religious status, a unique heritage that carries an effective combination of Romanesque and Baroque architectural styles manifested in the buildings of the complex. Various elements were added and subtracted through different periods making the whole setting unique and very rich. In addition, the cultural Galician heritage is still practiced at its best whether in their gastronomic and other customs and manners. This religious, historical, and cultural diversity make travellers' motivation vary greatly and comes to the fore religious and cultural reasons to enjoy sacred, artistic treasures, as well as to immerse in rich cultural traditions. From the religious viewpoint, however, and unlike the medieval pure religious motivations, visitors of Santiago site do not always have a purely religious or spiritual motives.

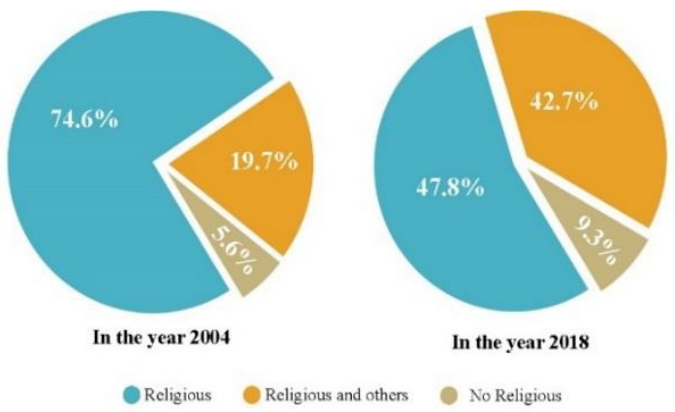

Figure 5- Ratio of pilgrimage Motivation [14]

The construction of the cathedral began in 1075 to serve the growing numbers of pilgrims. The Cathedral was originally designed in the Romanesque style, but a lot of its architectural elements were added through different periods. Due to the successive renovations and changes underwent throughout history, the decorations today seem like a puzzle, with figures and reliefs of different sizes and scales. The following are selected manifestations of such multi-layered historical elements:

- The Platerias façade (1103: 1117): It is in the southern end of the transept this only Romanesque façade that is left of the cathedral, maintaining its original architecture with barely any transformation, except for the addition of reliefs from other parts of the cathedral and the Clock Tower and the Treasury facade that flank it. The Clock Tower was built in the $14^{\text {th }}$ century in a Baroque style.

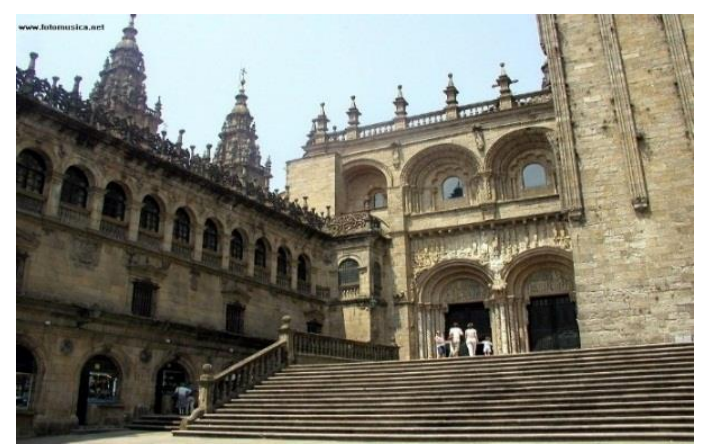

Figure 6- The Platerias façade (southern façade) [15]

- The Obradoiro façade (1738): The western façade of the medieval cathedral was documented in the drawings by Vega y Verdugo where, in 1738, Fernando de Casas demolished the ancient facade and began the works for the current one that bears little features of the glorious original portico. The intervention on the facade of Santiago cathedral comprised of a pyramidal central body with large windows that joined up with the two existing towers to create a symmetrical whole [16] 


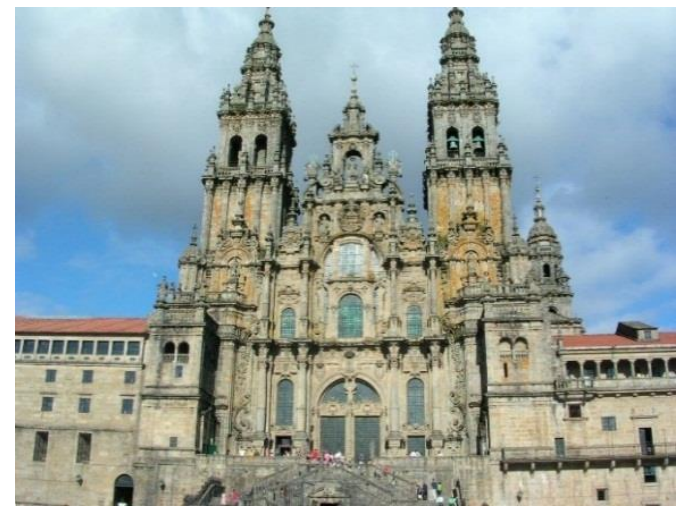

Figure 7- The Obradoire façade (north façade) [17]

- The Azabacheria façade (1758): The north façade, initially known as paradise façade, was demolished in 1758. The reconstruction was conceived in a Neoclassic style, although it also reveals some Baroque elements. As a result, some parts were transferred to the Platerias facade and others are now kept in the cathedral museum of Santiago.

- The Chevet (1658): At the east face of the cathedral, the chevet of the Romanesque Cathedral consisted of a series of chapels and gates with an irregular and asymmetric appearance. For this reason, to decorate and structure the surrounding space, the Canon Vega y Verdugo designed a closure for the chevet, whose works lasted until the 18th century. The result is an ornamental stone closure behind which there is a large amount of the original structure, organized into three Baroque fronts with an equal number of doors; the Royal Door, the Holy Door and the Door of the Abbots [16].

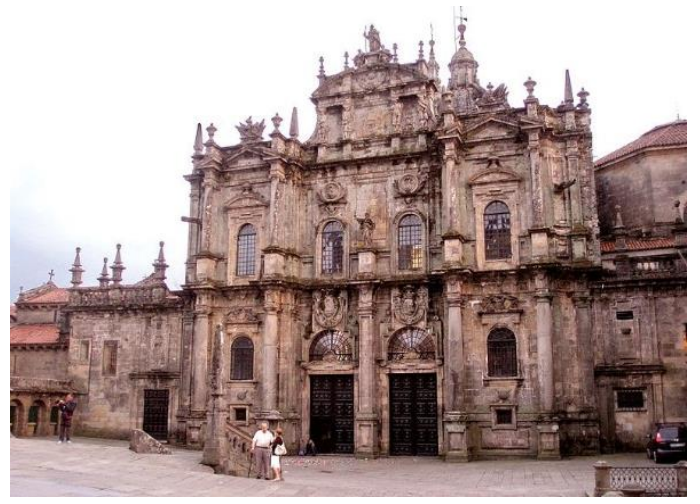

Figure 8- The Azabacheria façade [18]

Preservation problem: Since the restoration operations began in 2010, the original Romanesque configuration was ignored. It only focused on the developed facades that were added in consecutive phases. The interpretation was not offered to reveal the real history of the building and its origin. The various architectural and historic values were not considered, and the community posts were not respected in planning the visits to the cathedral. It is for that reason that the restoration was not supported by the local community and served only the visions of the Cathedral's bishops. The city around the Cathedral was kept in a stalemate.

Values and Attributes by Nara Grid: After collecting and studying the historic information about the cathedral, its history, the Nara Grid was applied and summarized in (Table 3). It became clear that the Cathedral was worth preserving due to:

- Romanesque features are clearly visible in the Platerias facade and surrounding squares.

- Architectural parts of the original façades are preserved in the Cathedral Museum.

- Ignoring Romanesque features weakens the heritage values of the cathedral, distorts the medieval pilgrimage period, and weakens visitors' attachment to the place.

- Roman building style, techniques, and elements reflect the great architecture of this period

Applying Nara Grid, the authenticity of the site was verified and the best approach for its preservation was evaluated. It indicated that the cathedral has many heritage values with artistic importance and that the architectural edifice carries many unique elements and artistic styles that are difficult to find in one building. This exceptional outstanding value explains the inclusion of the site in the World Heritage List. Rituals, however, were not substantially expressive.

\section{Case study (3): FUSHIMI INARI SHRINE IN}

\section{JAPAN}

Fushimi Inari Taisha is now known worldwide as one of the most iconic sights in Kyoto in specific, and in Japan in general. Fushimi Shrine is the head shrine of the Inari shrines, which reached, as said, to be around 30,000 sub-shrines dedicated to the god of rice, Inari in Japanese. The shrine sits at the base of a mountain also named Inari which is 233 meters above sea level and includes trails up the mountain to many smaller shrines. The oldest parts of the Fushimi Inari Shrine date back to year 711. In 1468 the shrine edifices both on the mountain and below are destroyed in a fire during the attack in Ōnin War of 1694. Shrine edifices were rebuilt. [19]

Visitors of this shrine pay respect to the kami, the good fortune. Shrines are also visited during special events such as New Year. Newly born babies are traditionally brought to a shrine a few weeks after birth, and many couples hold their wedding ceremonies there. Visitors could enjoy walking up the hillside, taking in the 


\section{Alaa E. El-Habashi, and Samah H. El-Refai" Pilgrimage Sites - Heritage Sites: The Evaluation of Authenticity of Selected Cases"}

beautiful views of the city, and walking through the tori (gates of the religious complex).

The tori (gates) trail up the mountains is very popular among Japanese and foreign tourists. On each gate, an inscription that shows the donor's name, which can either be of an individual or an institution; both are striving for good luck. It is said that there are more than 10,000 gates in the temple complex, dating back to a custom that spread in the Edo era (1603-1868), namely that everyone who fulfilled a wish was providing a gateway to the temple as an offering.

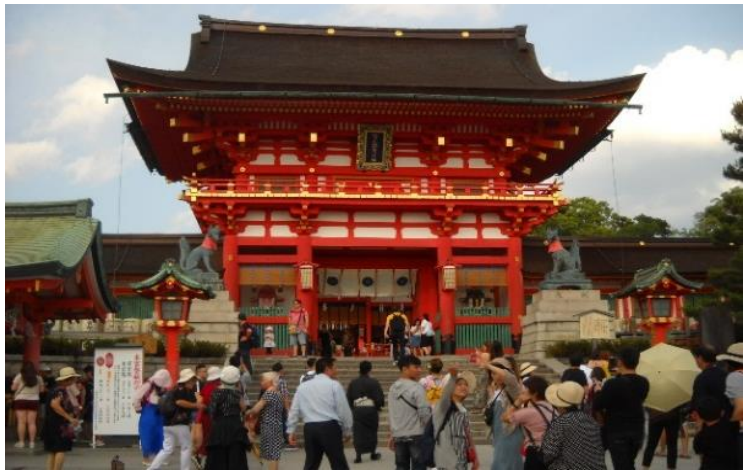

Figure 9- Fushimi Inari Shrine Perspective [19]

Throughout its 1000-year history, wood gates have resisted time factors thanks to the mercury-painted paint, which prevent wood from rotting. People who wish to pray for happiness, success in business or exams, but do not have a large pocket can buy smaller ornamental sized gate with their name painted on it. Tiny tori can be seen everywhere resting askew on the smaller sub-shrines, graves, or stacked up on fences [20].

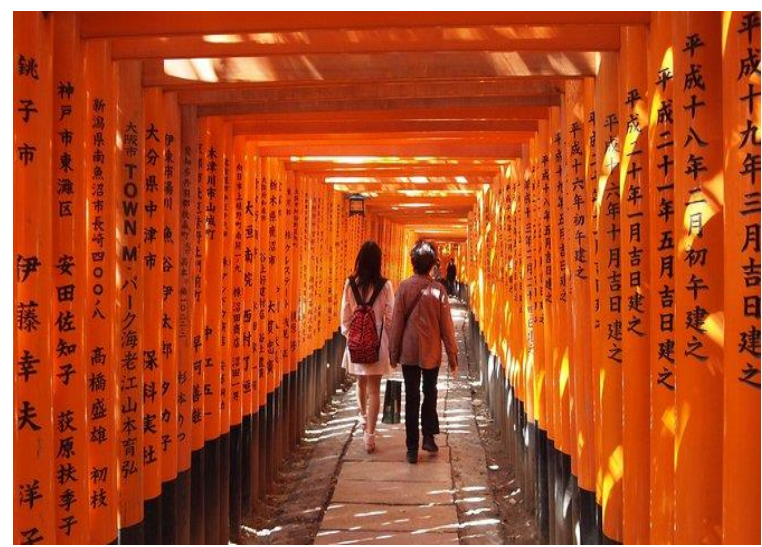

Figure 10- The tori of Fushimi Inari Shrine [21]

After studying the rituals and practices that visitors perform inside the site, the Nara Grid was developed and summarized in (table 4). The following are concluded:

- The authenticity of the heritage is confirmed. It really stems from a well-rooted culture. The authenticity of the built fabric was not on a primary concern. The amalgamation and harmony that existed between built fabric, the materials, the landscape, and the people were enriched by the values entailed in the shrine.

- The development and urbanization followed in dealing with heritage in Japan helped to integrate all human groups: children, youth, and the elderly. Flexibility in dealing with heritage strengthened people's culture and increased their attachment to their history and made them keen to preserve it.

- Individuals and institutions were treated as key partners in development. Through their continued support, Fushimi Inari Taisha was registered as a religious organization. It has become one of the highly ranked Cultural Property, besides its religious connotations.

- Through successful conscious management, the shrine was able to combine religious spirituality with historical facts without any conflict between them.

\section{Conclusions}

The following is a summary of the trends of preserving heritage in the three selected pilgrimage sites. This comparison checks on whether these unique historic and religious sites are reflected within the local culture or lowered down to be treated as solely religious with little cultural associations.

Makkah in Saudi Arabia is a case of extreme excessive ignorance towards heritage, this resulted in a false identity that reflects nothing but sorrow for the treasures that have been destroyed. The mismanagement resulted in a situation of visual distortion and complete loss of the site's authenticity. It has become difficult to consider this site a heritage site. However, the site attracts a large number of believers yearly for pilgrimage. The process, even though mostly departed from its spirituality, is flourishing in terms of demands. These consequences are reflected in the booming developments that are taking place in the site and its surrounding.

Santiago de Compostela in Spain is an example that represents a state of extreme rigidity in dealing with heritage attributes. Because of rigid adhering to the facades developed in different eras and ignoring medieval origins of the building that were present in the Romanesque era, a confused interpretation can always be resulted in determining the historical identity of the place. Despite this, it is possible to reexamine the situation and merge the preserved parts from the original facades. The fabric-oriented conservation has marginalized the community 


\section{Alaa E. El-Habashi, and Samah H. El-Refai" Pilgrimage Sites - Heritage Sites: The Evaluation of Authenticity of Selected Cases"}

participation and departed the Cathedral complex from the surrounding city. The Church that is becoming the center of the attention is benefiting the most from the on-going conservation, while the city around it is degrading and is not in immediate attention, with the exception of a little zone in the Church's immediate surroundings. While the church is getting more and more space and attention, the city is being marginalized; a scenario that is almost the opposite of Mecca.

Fushimi Inari Shrine in Japan is a case that represents a state of moderation and flexibility in dealing with heritage attributes. The idea of preserving the authenticity of the culture on which the shrine is based has been established to reach the desired harmony between the site and visitors without prejudice to spirituality and religious rituals. The built fabric is of secondary concern comparing to the value of religious and cultural practices. This made those intangible aspects well manifested throughout the site. The landscape and the surrounding become an integral component of the complex and an added meaning to it. The site however is losing gradually its religious importance for its cultural values that are prevailing and gradually taking over. The economical values are at their best since it became one of the most visited sites in Japan as opposed to the Mecca that is only reserved for Muslim pilgrims.

\section{Recommendations}

The comparison between the three pilgrimage sites indicates that each case has its advantages and disadvantages. If heritage is the main concern, it is for sure Santiago Cathedral that leads if the matter is the built fabric, followed by Fuhshimi shrine where traditions and intangible cultural believes prevails. Mecca is certainly a site that cannot be considered as heritage since heritage is totally overpowered by the religious and economic mandates. These recommendations are made to basically maintain a balance.

1. Dealing with the Hajj, as it is just a performed ritual, reduces the status and significance of the religious ritual. Heritage could have been used to incite spirituality, the purification of the soul, the enlightening of the mind, and the reviving of the soul. The restoration and the re-interpretation of cultural assets would regenerate those principles back to Hajj.

2. Striking a balance between religious spirituality and historical facts in pilgrimage sites enriches and supports the values of the place and the experiences of visiting it.

3. Identifying stakeholders, setting values, and defining attributes of these values, are indispensable steps in managing any heritage site, including pilgrimage sites.

4. The involvement of different stakeholders in making decisions related to preservation and the lack of uniqueness of any partner in developing a specific approach to preserve the site is the basis for the success.

\section{Future Studies}

This paper syntheses argument made in the Master thesis entitled 'The Assessment of the of the Condition of cultural heritage during the time of crisis' at the Menoufia University. This thesis aims at highlighting the role of preservation in the founding the local identity and the specificities of culture, and for that, it draws a new perspective for heritage preservation that based on the evaluation of authenticity and the identification of values and attributes of the selected sites, especially in heritage sites with religious associations in the Arab region. 


\section{Alaa E. El-Habashi, and Samah H. El-Refai "Pilgrimage Sites-Heritage Sites: The Evaluation of Authenticity of Selected Cases"}

Table 2- Completed Nara Grid for Makkah in Saudi Arabia

\begin{tabular}{|c|c|c|c|c|}
\hline \begin{tabular}{|l|c}
$\begin{array}{c}\text { Asp } \\
\text { ects }\end{array}$ & $\begin{array}{c}\text { Dimensi } \\
\text { ons }\end{array}$ \\
\end{tabular} & Artistic & Historic & Social & Scientific \\
\hline 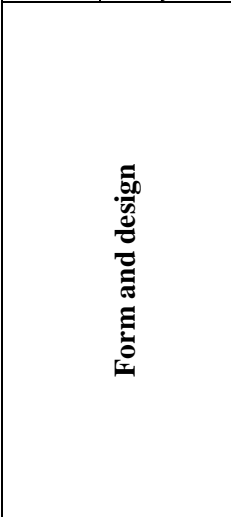 & $\begin{array}{l}\text { - The expansions that took } \\
\text { place in the courtyard } \\
\text { around the Kaaba } \\
\text { attempted to incorporate } \\
\text { some traditional } \\
\text { architectural elements and } \\
\text { treatments such as domes } \\
\text { and pointed arcades. }\end{array}$ & $\begin{array}{l}\text { - Some of the buildings } \\
\text { that were built decorated } \\
\text { with Arabic inscriptions } \\
\text { and topped by a crescent- } \\
\text { shape vertex in what feels } \\
\text { like a cynical nod to } \\
\text { Islam's architectural past. }\end{array}$ & $\begin{array}{l}\text { - Luxury buildings aimed } \\
\text { at profit and investment } \\
\text { make a sense of class and } \\
\text { inequality that exists for } \\
\text { many visitors. we find } \\
\text { rich sealed inside } \\
\text { exclusive air-conditioned } \\
\text { high-rises encircling the } \\
\text { Grand Mosque and the } \\
\text { poor pushed increasingly } \\
\text { to the periphery. }\end{array}$ & $\begin{array}{l}\text { - What came to us from } \\
\text { the designs of the old } \\
\text { buildings and their } \\
\text { façades illustrates the } \\
\text { development } \\
\text { architectural thought at } \\
\text { this time, where interest in } \\
\text { thermal comfort and the } \\
\text { various techniques to } \\
\text { reach it. The designs of } \\
\text { modern buildings reflect } \\
\text { the technological } \\
\text { development in the world } \\
\text { of construction. }\end{array}$ \\
\hline 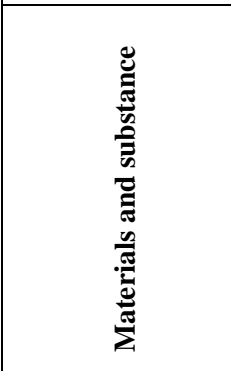 & $\begin{array}{l}\text { - Original materials used } \\
\text { are not visible it was a } \\
\text { unique artistic expression } \\
\text { of beauty and harmony } \\
\text { with the environment. }\end{array}$ & $\begin{array}{l}\text {-The materials used are all } \\
\text { modern building } \\
\text { materials such as concrete } \\
\text { and glass. But the missing } \\
\text { materials were explaining } \\
\text { the human relationship } \\
\text { with his environment } \\
\text { during the time of the } \\
\text { Prophet Muhammad and } \\
\text { his respect for it. }\end{array}$ & $\mathrm{X}$ & $\begin{array}{l}\text { - Use glass and concrete } \\
\text { bricks to construct these } \\
\text { massive structures. The } \\
\text { use of clay, palm leaves, } \\
\text { thatched and camel skin is } \\
\text { an evidence of the respect } \\
\text { for the environment and } \\
\text { coexistence with it in the } \\
\text { era of Muhammad. }\end{array}$ \\
\hline 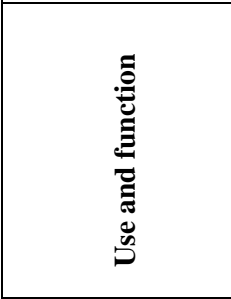 & $\begin{array}{l}\text {-The enormity of the } \\
\text { projects that were built } \\
\text { around the Kaaba and its } \\
\text { exaggerated architectural } \\
\text { style led to an imbalance } \\
\text { in the spiritual function of } \\
\text { the place. }\end{array}$ & $X$ & $\begin{array}{l}\text {-The Grand Mosque is } \\
\text { one of the few places in } \\
\text { the world where Muslims } \\
\text { of all stripes gather - } \\
\text { Sunnis and Shiites, } \\
\text { secular Muslims, mystics, } \\
\text { and hard-liners. }\end{array}$ & $\begin{array}{l}\text { The relationship between } \\
\text { the Kaaba and the } \\
\text { concrete blocks and the } \\
\text { formation of the urban } \\
\text { fabric of the city indicates } \\
\text { the absence of thought } \\
\text { and vision in the } \\
\text { construction process. }\end{array}$ \\
\hline 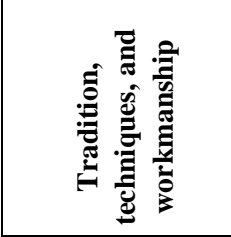 & $\begin{array}{l}\text {-The complete } \\
\text { disappearance of all the } \\
\text { old traditions and crafts } \\
\text { that were expressing this } \\
\text { era. }\end{array}$ & $\begin{array}{l}\text { - Some buildings used } \\
\text { traditional treatments to } \\
\text { shape the exterior façades } \\
\text { such as domes and } \\
\text { pointed arcades. }\end{array}$ & $\mathrm{X}$ & $\begin{array}{l}\text {-Some buildings used } \\
\text { traditional treatments to } \\
\text { shape the exterior façades } \\
\text { such as domes and } \\
\text { pointed arcades. }\end{array}$ \\
\hline 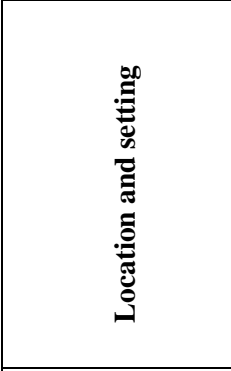 & $\begin{array}{l}\text {-The giant scale of the } \\
\text { projects surrounding the } \\
\text { Kaaba made us lose the } \\
\text { sense of the beauty and } \\
\text { spirituality of the place } \\
\text { The monumental luxury } \\
\text { hotel towers dwarfing } \\
\text { Kaaba. }\end{array}$ & $\begin{array}{l}\text { - The construction of } \\
\text { these expansions on the } \\
\text { heritage ruins of this place } \\
\text { cannot erase the unique } \\
\text { historical value of this } \\
\text { site. }\end{array}$ & $\begin{array}{l}\text { - New skyscrapers added } \\
\text { a spirit of alienation from } \\
\text { the place were blotting } \\
\text { out the surrounding } \\
\text { mountains which } \\
\text { represent sacred sites and } \\
\text { their looming presence } \\
\text { imbues the space with a } \\
\text { powerful sense of } \\
\text { intimacy. }\end{array}$ & $\mathrm{X}$ \\
\hline 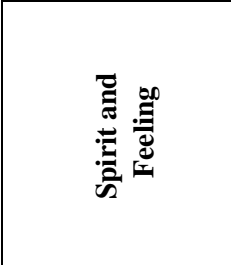 & $\begin{array}{l}\text {-The enormity of the } \\
\text { fabric surrounding the } \\
\text { Kaaba and the disposal of } \\
\text { all that is historical made } \\
\text { the place gradually lose } \\
\text { its sacred and spiritual } \\
\text { energy. }\end{array}$ & $\begin{array}{l}\text {-The holiness and } \\
\text { spirituality of the site and } \\
\text { the events it holds for the } \\
\text { spread of the Islamic call } \\
\text { is a unique historical case. }\end{array}$ & $\begin{array}{l}\text { - Luxury buildings } \\
\text { robbed the hajj of its more } \\
\text { than } 1,400 \text { year-old } \\
\text { message that all Muslims, } \\
\text { rich or poor, are equal } \\
\text { before God. }\end{array}$ & $\mathrm{X}$ \\
\hline
\end{tabular}




\section{Alaa E. El-Habashi, and Samah H. El-Refai "Pilgrimage Sites-Heritage Sites: The Evaluation of Authenticity of Selected Cases"}

Table 3- Completed Nara Grid Santiago de Compostela cathedral in Spain

\begin{tabular}{|c|c|c|c|c|}
\hline 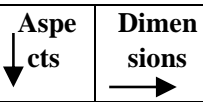 & Artistic & Historic & Social & Scientific \\
\hline 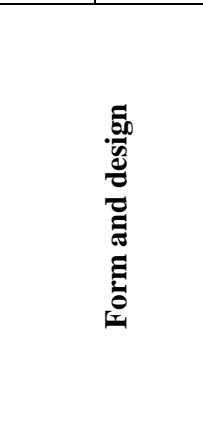 & $\begin{array}{l}\text { - The southern façade is } \\
\text { the only facade that still } \\
\text { conserves its original } \\
\text { Romanesque structure. } \\
\text { - Cathedral being a blend } \\
\text { of Romanesque, Gothic } \\
\text { \& Baroque architecture } \\
\text { styles. }\end{array}$ & $\begin{array}{l}\text { - The facades full of } \\
\text { architectural elements and } \\
\text { ornamentation dating back } \\
\text { to different time periods. } \\
\text { - The Praterías facade is } \\
\text { Romanesque and a } \\
\text { paradigm of medieval } \\
\text { religious art. }\end{array}$ & $\begin{array}{l}\text { - The facades feature } \\
\text { many Romanesque } \\
\text { sculptures which refer to } \\
\text { major figures from the } \\
\text { Bible, with the Old } \\
\text { Testament and its } \\
\text { prophets, Apostles and } \\
\text { glory and resurrection } \\
\text { depicted. These sculptures } \\
\text { evoke the feelings of } \\
\text { visitors to the cathedral. }\end{array}$ & $\begin{array}{l}\text { - The remains of the building } \\
\text { forms and original sculptures } \\
\text { are a reliable scientific } \\
\text { source for the architectural } \\
\text { and engineering typology of } \\
\text { this era. }\end{array}$ \\
\hline 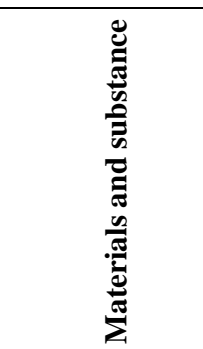 & $\begin{array}{l}\text { - Over the centuries the } \\
\text { used Original materials } \\
\text { generally has suffered } \\
\text { considerable wear and } \\
\text { tear from water seepage } \\
\text { and humidity but the rest } \\
\text { of it is a unique } \\
\text { architectural expression. }\end{array}$ & $\begin{array}{l}\text { - These materials are very } \\
\text { resistant since there are still } \\
\text { roman structures standing } \\
\text { more than } 2000 \text { years. }\end{array}$ & $\mathrm{X}$ & $\begin{array}{l}\text { - Evidence of the Romans' } \\
\text { skill in producing concrete to } \\
\text { be highly preserved. Asian } \\
\text { Romans' concrete consists } \\
\text { of lime water, sand and } \\
\text { pozzolana. Pozzolana is } \\
\text { made up of volcanic ash, } \\
\text { water, and stone. }\end{array}$ \\
\hline 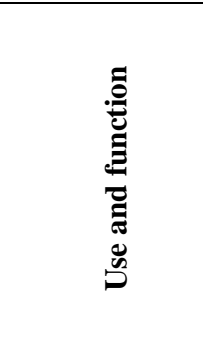 & $\begin{array}{l}\text { - The original } \\
\text { Romanesque structure } \\
\text { represents the traditional } \\
\text { design of the cathedral } \\
\text { where Latin-cross layout } \\
\text { and three naves, } \\
\text { separated by majestic } \\
\text { lines of Romanesque } \\
\text { arches }\end{array}$ & $\begin{array}{l}\text { - Not only functioning as a } \\
\text { monument for St. James the } \\
\text { Greater, Santiago de } \\
\text { Compostela also acts as a } \\
\text { major pilgrimage route } \\
\text { since early Middle Ages. }\end{array}$ & $\begin{array}{l}\text { - The Galician tomb } \\
\text { placed in the cathedral had } \\
\text { also been the symbol of the } \\
\text { resistance of Spanish } \\
\text { Christians against Islam } \\
\text { over a millennium since it } \\
\text { was destroyed by the } \\
\text { Muslims at the end of the } \\
\text { 10th century. }\end{array}$ & $\mathrm{X}$ \\
\hline 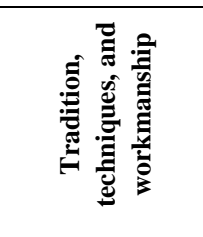 & $\begin{array}{l}\text { - The cathedral is an } \\
\text { artwork that reflects } \\
\text { building techniques in } \\
\text { this era. }\end{array}$ & $\begin{array}{l}\text { - The cathedral is a } \\
\text { historical reference for } \\
\text { traditional skills and } \\
\text { techniques in three different } \\
\text { eras. }\end{array}$ & $\begin{array}{l}\text {-The cathedral reflects the } \\
\text { skill of professional } \\
\text { craftsmen in different } \\
\text { specialties and their role in } \\
\text { the construction and } \\
\text { restoration processes. }\end{array}$ & $\begin{array}{l}\text {-Possibility to study ancient } \\
\text { techniques } \\
\text { craftsmanship (e.g., the } \\
\text { barrel vault semi-circular } \\
\text { arches). }\end{array}$ \\
\hline 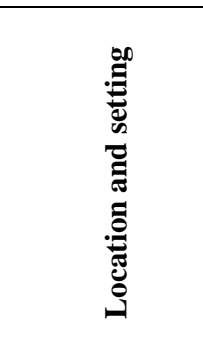 & $\begin{array}{l}\text { - The cathedral is in the } \\
\text { heart of the city, where all } \\
\text { roads into the city } \\
\text { converge that draws } \\
\text { attention to it. }\end{array}$ & $\begin{array}{l}\text { - The cathedral is still } \\
\text { standing as a famous church } \\
\text { and tourist attraction that } \\
\text { compose of different } \\
\text { characteristics where It is } \\
\text { one of the few cathedrals } \\
\text { with these characteristics. }\end{array}$ & $\begin{array}{l}\text { - The Cathedral stands in } \\
\text { the lovely Plaza del } \\
\text { Obradoiro square where } \\
\text { pilgrims buy the traditional } \\
\text { pewter or tin shell } \\
\text { souvenirs of St. James. } \\
\text { The plaza is still a leading } \\
\text { tourist attraction and } \\
\text { continues to sell souvenirs. }\end{array}$ & $X$ \\
\hline 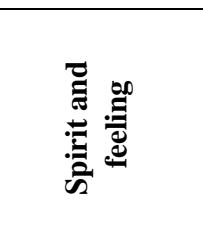 & $\begin{array}{l}\text { - The artistic creativity } \\
\text { found in this architectural } \\
\text { edifice creates a state of } \\
\text { admiration and } \\
\text { fascination within the } \\
\text { hearts of visitors. }\end{array}$ & $\begin{array}{l}\text { - The Cathedral itself } \\
\text { consists of } 3 \text { architectural } \\
\text { styles, where each of the } \\
\text { styles reflects the different } \\
\text { spirit of time and place. }\end{array}$ & $\begin{array}{l}\text { - The building and } \\
\text { renovations that took place } \\
\text { are far from the } \\
\text { Romanesque style, } \\
\text { creating a state of spiritual } \\
\text { separation from the place. }\end{array}$ & $X$ \\
\hline
\end{tabular}




\section{Alaa E. El-Habashi, and Samah H. El-Refai" Pilgrimage Sites - Heritage Sites: The Evaluation of Authenticity of Selected Cases"}

Table 4- Completed Nara Grid for Fushimi Inari Shrine in Japan

\begin{tabular}{|c|c|c|c|c|}
\hline \begin{tabular}{|c|c}
$\begin{array}{c}\text { Aspe } \\
\text { cts }\end{array}$ & $\begin{array}{c}\text { Dimen } \\
\text { sions }\end{array}$ \\
\end{tabular} & Artistic & Historic & Social & Scientific \\
\hline 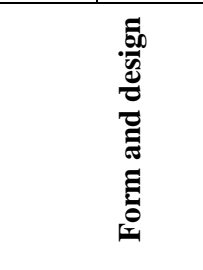 & $\begin{array}{l}\text { - The design of the shrine } \\
\text { stems from the dominant } \\
\text { architectural style of } \\
\text { building design in Japan } \\
\text { in perfect harmony with } \\
\text { nature. }\end{array}$ & $\begin{array}{l}\text { - At the shrine's entrance } \\
\text { stands the Romon Gate, } \\
\text { which was donated in } \\
1589 \text { by the famous leader } \\
\text { Toyotomi Hideyoshi. }\end{array}$ & $\begin{array}{l}\text { - In Fushimi Inari Taisha } \\
\text { Shrine, you can get a brief } \\
\text { glimpse of ancient } \\
\text { Japanese culture, As the } \\
\text { design of the shrine stems } \\
\text { from ancient Japanese } \\
\text { beliefs. }\end{array}$ & $\begin{array}{l}\text { - The building is a reliable } \\
\text { scientific source for the } \\
\text { architectural and } \\
\text { engineering typology of } \\
\text { this era. }\end{array}$ \\
\hline 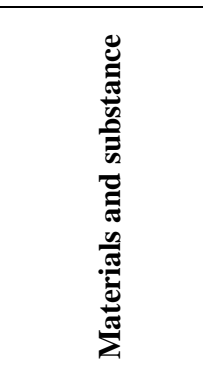 & $\begin{array}{l}\text { - Original materials used } \\
\text { are visible and are mainly } \\
\text { in good condition; they } \\
\text { enhance the beauty of } \\
\text { architecture. }\end{array}$ & $\begin{array}{l}\text { - The used material } \\
\text { represents a classic view } \\
\text { for the traditional } \\
\text { Japanese creativity. }\end{array}$ & $\mathrm{X}$ & $\begin{array}{l}\text { - The torii gates are made } \\
\text { of wood, wood gates have } \\
\text { resisted time factors } \\
\text { thanks to the mercury- } \\
\text { painted paint gates, which } \\
\text { prevent wood from rotting } \\
\text { throughout these } \\
\text { historical periods }\end{array}$ \\
\hline 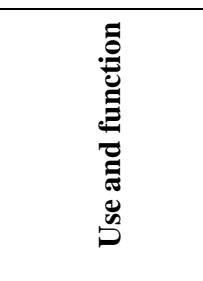 & $\begin{array}{l}\text {-The sight of torii gates } \\
\text { continuing one after the } \\
\text { other is mysterious and } \\
\text { something you will be } \\
\text { hard-pressed to forget. It } \\
\text { evokes a sense of } \\
\text { adventure for visitors. }\end{array}$ & $\begin{array}{l}\text { - One of the most well- } \\
\text { known and popular } \\
\text { shrines in all of Kyoto It is } \\
\text { the head shrine of all Inari } \\
\text { Shrines that number as } \\
\text { many as } 32,000 \text { in Japan. }\end{array}$ & $\begin{array}{l}\text { - The rituals and different } \\
\text { practices that take place in } \\
\text { the shrine helped create a } \\
\text { state of societal } \\
\text { integration and emotional } \\
\text { friendship to the place. }\end{array}$ & $\mathrm{X}$ \\
\hline 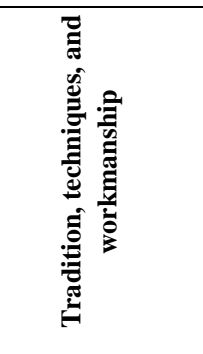 & $\mathrm{X}$ & $\begin{array}{l}\text { - Fushimi Inari was a } \\
\text { place to pray for a good } \\
\text { harvest, but as the times } \\
\text { changed, so did Fushimi } \\
\text { Inari: now the shrine is } \\
\text { also a place where you } \\
\text { can pray for thriving } \\
\text { business and the well- } \\
\text { being of your family. }\end{array}$ & $\begin{array}{l}\text { - The Shrine reflects the } \\
\text { skill of professional } \\
\text { craftsmen in different } \\
\text { specialties and their role } \\
\text { in the construction and } \\
\text { restoration processes. }\end{array}$ & $\begin{array}{l}\text { - Possibility to study } \\
\text { ancient techniques and } \\
\text { craftsmanship. }\end{array}$ \\
\hline 泀 & $\begin{array}{l}\text { - The shrine sits at the } \\
\text { base of a mountain also } \\
\text { named Inari which is } 233 \\
\text { metres above sea level. } \\
\text { This allows the visitor to } \\
\text { blend with nature and } \\
\text { enjoy the wonderful } \\
\text { views. }\end{array}$ & $\begin{array}{l}\text { - This shrine is the central } \\
\text { location for some } 40,000 \\
\text { Inari shrines throughout } \\
\text { the entirety of Japan. }\end{array}$ & $\begin{array}{l}\text { - The site increases } \\
\text { community integration } \\
\text { where, if you reach the top } \\
\text { of the mountain, you'll } \\
\text { notice seemingly } \\
\text { countless prayer mounds } \\
\text { which draw literally } \\
\text { millions of local tourists } \\
\text { each Japanese New Year. }\end{array}$ & $\begin{array}{l}\text { - Reflects a clear picture } \\
\text { of cultural landscape } \\
\text { where Dozens of sub- } \\
\text { temples and shrines exist } \\
\text { as you walk up the more } \\
\text { than two miles to the top } \\
\text { of Mount Inari, which } \\
\text { gives you dramatic } \\
\text { panoramic views of } \\
\text { Kyoto below. }\end{array}$ \\
\hline 承 & $\begin{array}{l}\text { - The spirituality in place } \\
\text { adds beauty, simplicity, } \\
\text { and harmony. }\end{array}$ & $\begin{array}{l}\text { - Fushimi Inari was a } \\
\text { place to pray for a good } \\
\text { harvest, but as the times } \\
\text { changed, so did Fushimi } \\
\text { Inari: now the shrine is } \\
\text { also a place where you } \\
\text { can pray for thriving } \\
\text { business and the well- } \\
\text { being of your family. }\end{array}$ & $\begin{array}{l}\text {-The practices that take } \\
\text { place in the shrine increase } \\
\text { social integration and a } \\
\text { passion for the place, where } \\
\text { visitors who have wishes } \\
\text { they want to be fulfilled, } \\
\text { will write these wishes on } \\
\text { the ema and hang them up } \\
\text { at the shrine. }\end{array}$ & $X$ \\
\hline
\end{tabular}




\section{Alaa E. El-Habashi, and Samah H. El-Refai" Pilgrimage Sites - Heritage Sites: The Evaluation of Authenticity of Selected Cases"}

\section{References}

[1] "Fushimi Inari Taisha," History, [Online]. Available: http://inari.jp/en/history/. [Accessed 32 2020].

[2] M. L. Mona Moufahima, "Pilgrimage, consumption and rituals: Spiritual authenticity in a Shia Muslim pilgrimage," Tourism Management, vol. 70, p. 322, 2019.

[3] K. C. S. Yaniv Belhassen, "The search for authenticity in the pilgrim experience," Annals of Tourism Research, p. 683, 2008.

[4] S. Denyer, "Retrospective Statements of OUV for World Heritage Properties: Authenticity \& Integrity," 2nd Cycle of World Heritage Periodic, Dublin, 2011.

[5] K. V. Balen, "The Nara Grid:An Evaluation Scheme Based on the Nara Document on Authenticity," APT Bulletin, p. 40, 2008.

[6] M. d. 1. Torre, "Values and Heritage Conservation," Heritage \&Society, p. 4, 2013.

[7] K. Bureau, "The Charter of Krakow Principles for Conservation and Restoration of Built Heritage," Smart Heritage, 2015. [Online]. [Accessed 52 2020].

[8] ICOMOS, "The Burra Charter: The Australia ICOMOS Charter for Places of Cultural Significance," ICOMOS, 1999. [Online]. Available: https://australia.icomos.org/wpcontent/uploads/BURRA_CHARTER.pdf. [Accessed $2552020]$.

[9] ICOMOS, "Burra Charter for the Conservation of Places of Cultural Significance," ICOMOS, 2013. [Online]. Available. https://australia.icomos.org/wpcontent/uploads/The-Burra-Charter-2013-Adopted31.10.2013.pdf. [Accessed 252 2020].

[10] Nuzha Al Jabri, - Rayan Alhazmi, "Observing and Monitoring the Urban Expansion of Makkah alMukarramah Using the Remote Sensing and GIS," AJSRP, p. 6, 2017.

[11] I. E. Ascoura, "Impact of Pilgrimage (Hajj) on the Urban Growth of the Mecca," Journal of Educational and Social Research, vol. Vol. 3 (2), p. 260, 2013.

[12] "THE DESTRUCTION OF ISLAMIC HERITAGE IN SAUDI ARABIA," The Academic Center for Shi'a Studies, 2015.
[13] A. TAYLOR, "Mecca Then and Now, 128 Years of Growth," The Atlantic, 299 2015. [Online]. [Accessed 241 2020].

[14] "Ajyad Fortress," Makkah Vibes, 592017. [Online]. Available: https://makkahvibes.com/363. [Accessed 231 2020].

[15] "Statistics," Oficina De Acogida Al Peregrino, [Online]. Available: https://oficinadelperegrino.com/en/statistics/. [Accessed 301 2020].

[16] "Galicia," foto musical, [Online]. Available: https://fotomusica.net/Galicia/asanti96.htm.

[Accessed 301 2020].

[17] "Art," Cathedral De Santiago, [Online]. Available:

http://catedraldesantiago.es/en/cathedral/\#art.

[Accessed 301 2020].

[18] "File: Cathedral de Santiago de Compostela. Agosto 2005.JPG," Wiki Media Commons, [Online]. Available:

https://commons.wikimedia.org/wiki/File:Catedral_d e_Santiago_de_Compostela._Agosto_2005.JPG.

[Accessed 301 2020].

[19] "Visiting the Cathedral of Santiago de Compostela," Santiago Ways, [Online]. Available: https://santiagoways.com/en/what-to-see-inside-thesantiago-cathedral. [Accessed 251 2020].

[20] "Fushimi Inari Taisha Shrine, The Mountain with Ten Thousand Gates," Awandering Foodie, [Online]. Available:

https://www.awanderingfoodie.com/fushimi-inaritaisha-shrine/. [Accessed 252 2020].

[21] "Fushimi Inari and Sake Tasting Tour," Viator, [Online]. Available: https://www.viator.com/enMY/tours/Kyoto/Fushimi-Inari-and-Sake-BreweryTour/d332-5163_SAKE. [Accessed 32 2020]. 